\title{
20. ONE-STOP GUIDANCE SERVICE CENTRES IN FINLAND
}

\begin{abstract}
This chapter describes Finnish efforts to introduce and expand the service model known as the 'One-Stop Guidance Centre' as a tool for Youth Guarantee implementation. A One-Stop Guidance Centre is a physical location where a young person can access the entire service provision. Firstly, the chapter explores the levels of youth unemployment in Nordic countries. Secondly, the evolution and development of the One-Stop Guidance Centres based on the private-public-peoplepartners approach is presented. Lastly, some emerging outcomes are reviewed.
\end{abstract}

\section{INTRODUCTION}

Youth inclusion in the labour market is a major challenge across much of Europe, including the Nordic countries (e.g. Eurostat, 2019; Halvorsen \& Hvinden, 2015). At times of economic transformation, young people are usually the most vulnerable group and encounter greater difficulties when entering the labour market. The complexity of this transition reflects four interrelated challenges: school dropout, lack of employment opportunities, labour market segmentation - that is, the employment of young workers on different terms, conditions and opportunities from older workers - and early exit and termination of contracts (Halvorsen \& Hvinden, 2015). Young people are often offered temporary (short-term) contracts, must usually accept less favourable working conditions because their limited professional experience, and are at greater risk of losing their job than older workers (e.g. Bussi \& Geyer, 2013; O'Higgins, 2010). If employers are reducing their workforce to adjust to a lower turnover, young people without work experience are less likely to be hired and are often the first to be dismissed from their employment contract (Halvorsen \& Hvinden, 2015).

In 2013, the member states of the European Union (EU) agreed to launch the Youth Guarantee to tackle youth unemployment. This EU initiative aims to provide all under-25-year-olds with an offer of good quality employment, continued education, an apprenticeship or traineeship within a period of four months of becoming unemployed or leaving formal education (European Council, 2013). Some Nordic countries (Denmark, Finland and Sweden), as well as Austria and Germany, 
have even opted for a shorter period of three months (Escudero \& López Mourelo, 2017). The Youth Guarantee is among the most comprehensive and innovative labour market policies of the last few decades and has received strong support and additional funding in many countries from all stakeholders, including governments, social partners and civil society (e.g. Escudero, Kûhn, López Mourelo, \& Tobin, 2018; Escudero \& López Mourelo, 2015). On the other hand, the available funding can also be an issue because the effective implementation of the Youth Guarantee is resource intensive and requires substantial public- or private-sector investment (O’Reilly et al., 2015).

The idea of a Youth Guarantee first emerged in the 1980s and 1990s in the Nordic countries. This is unsurprising, as these countries have long pioneered labour market policies for activation (Escudero \& López Mourelo, 2015). Sweden introduced the first Youth Guarantee in 1984, followed by Norway in 1993. Denmark and Finland introduced their Youth Guarantee programmes in 1996 as a more innovative and effective means of addressing deficiencies in youth employment (ILO, 2013; Mascherini, 2012; OECD, 2015). Although introduced amid many difficulties, these projects proved valuable as a basis for future efforts (Hummeluhr, 1997).

Given that young people are a diverse group, the Youth Guarantee programme (European Council, 2013) takes as its starting point the need to tailor all measures to each individual seeking employment. Implementation of this scheme commonly necessitates the reform of professional training systems, education systems and the public employment service (PES). Indeed, in many countries these structural changes or reforms are required to ensure individual young people receive appropriate advice on the job, education, and training opportunities most relevant to their own needs within a four-month timeframe (e.g. Escudero \& López Mourelo, 2015; O'Reilly et al., 2015). The European Lifelong Guidance Policy Network (ELGPN) Concept Note on the Youth Guarantee and lifelong guidance (Borbély-Pecze \& Hutchinson, 2013) was designed to support national administrations in responding to these challenges. Borbély-Pecze's and Hutchinson (2013) contended that successful and sustainable implementation of the initiative would depend on the effective integration of lifelong guidance practice into national Youth Guarantee programmes. Lifelong guidance in this context refers to a range of activities that support citizens to identify their capacities, competencies and interests and to make career decisions that enable them to manage their own life paths in learning, work and other settings. Without this, they argued, the Youth Guarantee would produce only temporary and short-term activities to 'get young people off the streets'. With proper integration, however, the initiative could become a 'springboard to a better future' (Borbély-Pecze \& Hutchinson, 2013, p. 18).

With the growing complexity of societies and labour markets, one of the key roles of guidance services is to help individuals to develop the necessary skills to transition effectively through learning and work for personal and career purposes. In this regard, the wider paradigm of lifelong guidance is seen as an important 
cross-cutting theme, linking policy fields such as schools, vocational education and training (VET), higher education, adult learning, employment and social inclusion, as well as horizontal policies related to youth, active ageing and citizens with special needs (Hooley, 2014).

National Youth Guarantee programmes include measures to provide education, targeted training or employment opportunities for young people. Although these national schemes are based on the European Youth Guarantee policy framework and must meet certain criteria, their design and implementation varies widely from country to country (Escudero \& López Mourelo, 2015). This chapter begins by introducing the youth unemployment trends in Nordic countries and the 'onestop' concept of service delivery before introducing the Finnish One-Stop Guidance Centre approach as a tool for Youth Guarantee implementation.

\section{YOUTH UNEMPLOYMENT TRENDS IN NORDIC COUNTRIES}

The many similarities between Nordic countries include training and labour market conditions for young people. As compared to other European countries, a high proportion of young people complete a more extensive education, with relatively fewer 15-24-year-olds outside both the education system and the workforce. On closer examination, however, some significant differences emerge between Nordic countries in relation to entry conditions for young people (Olofsson \& Wadensjö, 2012).

Youth unemployment rates are used by public employment services and other public institutions as indicators for adjusting intervention and integration measures. The youth unemployment rate is the number of unemployed 15-24-year-olds expressed as a percentage of the youth labour force. According to Eurostat (2019), overall youth employment in EU Member States stood at 15.2\% in 2018. In Nordic countries, the highest rates were in Finland (17.0\%) and Sweden (16.8\%) while the lowest was Iceland (6.1\%). Although rates in Finland and Sweden exceed the EU average this does not necessarily mean that a large number of 15-24-year-olds are unemployed (Grunfelder, Rispling, \& Norledn, 2018). In these statistics young people are classified as unemployed if they report that they are without work, that they are available for work and that they have taken active steps to find work in the last four weeks. In reality, there are a great number of full-time students among unemployed young people who are seeking, for example, part-time employment during studies or work during summer holidays. For example, in 2015, more than half of those young people included in the unemployment rate in Finland were actually students enjoying public student benefits (Official statistics of Finland, 2016). Eurostat unemployment statistics, in line with ILO standards, do not exclude students from unemployment just because they are students. Because not every young person is in the labour market, the youth unemployment rate does not reflect the proportion of all young adults who are unemployed (Eurostat, n.d.). A more 
realistic figure is the youth unemployment ratio, which measures the number of unemployed young people in relation to the total population of young people of the same age. The youth unemployment ratio is by definition always smaller than the youth unemployment rate, typically less than half of it. This difference is entirely due to the different denominators (Eurostat, n.d.). In the Nordic countries in 2018, the lowest youth unemployment ratio for 15- to 24-year-olds was in Iceland (4.9\%), followed by Norway (5.3\%) while the highest were in Sweden (9.1\%) and Finland $(9.0 \%)$ (Eurostat, 2019). Although the rates in Finland were high, Finnish youth are usually unemployed for a short time (OECD, 2019b). The average duration was only 3.3 months, which was the second lowest duration among the nine OECD countries for which the statistic was available. In Norway, the average length of unemployment spell was 4.6 months. According to OECD (2019b) in 2017 the share of youths in Finland who remain unemployed for half a year or longer was $14.3 \%$ while the share across the OECD was twice as high (28.9\%). In Norway and Sweden $30.9 \%$ and 21.5 of unemployed youth, respectively, were in this category in 2017.

As a Nordic welfare society, Finland performs well on many indicators, but the current state of youth unemployment remains a cause for concern. To improve implementation of the Youth Guarantee programme (European Council, 2013), Finland has concentrated on the introduction and expansion of the 'One-Stop Guidance Centre' service model, which is a joint initiative endorsed by the Ministry of Economic Affairs and Employment, the Ministry of Education and Culture and the Ministry of Social Affairs and Health. It was decided that the 2014-2020 European Social Fund (ESF) funding for the Youth Guarantee (under the auspices of the Ministry of Economic Affairs and Employment) would be allocated to the development and coordination of One-Stop Guidance Centres.

\section{ONE-STOP GUIDANCE CENTRES}

Although the 'one-stop' concept of service delivery is not new (see Hellerman, 1975), it has only recently come to prominence in the reinvention of employment and related social services delivery. Several countries have developed one-stop centres for careers and employment advice and guidance and counselling, with services provided under one roof (OECD, 2004, 2019a). One-stop centres have evolved to address problems that include fragmentation, lack of collaboration, limited resources and duplication of employment and related social services (Sampson \& Reardon, 1998). Four basic design principles have guided the development of this one-stop approach: (a) universal access, (b) customer choice, (c) integrated services and (d) accountability. Universal access provides customers with easy and in some cases unrestricted access to the information and services they need. Customer choice enables individuals to decide which services are most appropriate to their needs, including self-help options. Integrated services minimise fragmentation, duplication and resource limitations by encouraging service providers to collaborate, 
establishing common service functions (e.g. intake) and sharing infrastructure (e.g. data management). Accountability shapes the evolution of one-stop centres by emphasising performance driven or outcome-based services (Sampson \& Reardon, 1998). The one-stop approach can be implemented either as a traditional physical office or as a virtual location on a digital platform (e.g. Arnkil, Spangar, \& Vuorinen, 2017; ELGPN, 2010), or as a mix of these.

Frequently referred to as one-stop shops or centres, or more generally as integrated services, the actual structure of these facilities and the services they provide differs widely (Minas, 2014), ranging from co-location to integration of separate organisations (Sampson, McClain, Musch, \& Reardon, 2017). Sveriges Kommuner och Landsting (2017) identified three types of one-stop guidance centre in the Baltic Sea Region. The first of these is the one-stop centre as programme; specialists typically provide guidance counselling and coaching and psychological counselling, and help users to find internships, vocational training opportunities or jobs. Operations depend on access to funding and are usually project-based as an independent adjunct to existing services. The second type of one-stop centre offers the usual a la carte services and activities, complemented by employment measures. This entails close cooperation with public employment services, social insurance agencies and other relevant actors, who are either kept informed or are invited to run certain activities. In some cases, a centre coordinator mediates cooperation among these government institutions and other actors to provide the necessary support to users. The third and final type is collaboration-based and involves the most developed level of integration and institutional cooperation. Vertical and horizontal levels of governance at one location ensure a clear chain of events once the young person's needs, qualities and strengths have been defined. In practice this means that all services are located in the same building, and in many cases, a designated case officer guides the service user, with interaction and follow-up to ensure successful return to or integration at school, in the labour market or in society. Emphasis is put on active measures that intend to integrate the person into the labour market. Staff in the One-Stop Guidance Centres are recruited by the relevant institution (e.g. municipality, educational institution, the social insurance institution, public employment services, etc.) but are based on the premises.

\section{ONE-STOP GUIDANCE CENTRES IN FINLAND}

The Finnish One-Stop Guidance Centre (Ohjaamo in Finnish) concept is founded on European Council initiative: the Recommendation on Establishing a Youth Guarantee (European Commission, 2012, 2013).

\section{Evolution and Development of the One-Stop Guidance Centres}

In 2007-2018, Finland introduced several policy initiatives and national development projects to enhance networked guidance services, with support from 
the ESF. The introduction of One-Stop Guidance Centres in Finland was driven by studies commissioned by the Ministry of Economic Affairs and Employment (e.g. Harju et al., 2014) that asked young persons under the age of 25 years about their service needs and their views on the Finnish PES system. The results showed that young people favour face-to-face rather than online services. While e-services were considered useful for general support, they preferred to discuss matters of importance in person with a specialist in that area. Additionally, there is evidence (e.g. Notkola et al., 2013) of overlaps and complexity in the structure of services that need to be jointly addressed (Savolainen, Virnes, Hilpinen, \& Palola, 2015). Despite the number of services available, the overall service was seen to be somewhat fragmented; where there were multiple issues to discuss, young people had to make multiple appointments with different offices, making it difficult to benefit from the service when it was most needed. This also meant that no service provider had a holistic overview of the young person's situation across all aspects of their life, (Savolainen, et al., 2015) and, as a result of this, the threshold for seeking help at all might become too high.

Since early 2013, Finland has focused on regional and cross-sectoral employment and education priorities, supported by co-operative developments in lifelong learning and lifelong guidance (LLG) (see Toni \& Vuorinen, Chapter 9, this volume, for a wider commentary on Finnish career guidance policy). The development, design and implemention of guidance services is undertaken by 15 regional authorities through ELY Centres (Centre for Economic Development, Transport and the Environment) which all have established regional lifelong guidance forums. This work is coordinated by a government-designated national working group, with a mandate from the Ministry of Education and Culture and the Ministry of Employment and the Economy. In its first working period (2010-2011), the group launched a national LLG strategy for both sectors for the years 2012-2016. A new group was designated in February 2015, with a mandate covering the years 2015-2020. This group remained in place to update the strategy for the years 2016-2020 and to follow up its implementation and to serve as an Advisory Group for national guidance development programmes.

Partly in response to the above findings, the Finnish PES sought to develop OneStop Guidance Centres focused on youth, with the help of the national working group, the trade unions and a number of ministries. The positive experience of services already developed (Keränen, 2012) and the desire to make it easier for young people to find employment and education contributed to the decision. The first One-Stop Guidance Centre for young people opened in autumn 2014 as an element of Youth Guarantee implementation, and the practice was rolled out nationwide in 2015 with ESF support. One-Stop Guidance Centres have also been established by local authorities, with no external project funding. To ensure that the system of services is feasible and cost-efficient, there is a growing tendency to increase service users' involvement in the co-development and co-production of 
services (Saarelainen, Mäensivu, \& Minkkinen, 2018), building on what is known as the 4P approach (private-public-people-partnership) ( $\mathrm{Ng}$, Wong, \& Wong, 2013), which has been in place since 2013.

The 4P framework embraces bottom-up participative strategies that place public engagement at the heart of infrastructure planning and policy making. Through this proactive engagement, decision-making power shifts from policy makers traditionally the ultimate decision authority - to citizens. This strategy enhances the development process by moderating the risk of unforeseen opposition, building clear responsibilities and rights and creating opportunities for public input ( $\mathrm{Ng}$ et al., 2013). Successful partnerships achieve their objectives more effectively when all stakeholders are actively involved (Mohr \& Spekman, 1994).

Reconciling different operative and guidance cultures and establishing collaboration-based One-Stop Guidance Centres (Sampson et al., 2017; Sveriges Kommuner och Landsting, 2017) with common concepts and ways of working have taken time. In the development phase, the definition of what constitutes a One-Stop Guidance Centre remained deliberately quite loose, leaving room to adapt the concept to local conditions. Staff from different organisations simultaneously identify with their home organisation and the One-Stop Guidance Centre network and its goals. In nearly all of the centres, young people also participate in operational planning and contribute to brainstorming and planning at the launch stage. As geographic location and conditions in the municipality also have an impact on operations, the organisational model for services varies, and each One-Stop Guidance Centre is different (Kautto, Korpilauri, Pudas, \& Savonmäki, 2018).

\section{Objective and Operations of Finnish One-Stop Guidance Centres}

One-Stop Guidance Centres have now been placed on a permanent footing, and the network of centres has been expanded (Prime Minister's Office Finland, 2018) as a Youth Guarantee implementation tool right across Finland. In spring 2019, there were almost 70 centres in total, with about 500 professionals from different sectors working there on at least one day each week. The centres operate in more than 100 municipalities, from Finland's metropolitan capital to the rural heartlands.

The overarching objective is to provide low-threshold service points for young people up to the age of 30 years. This 'user interface' supports access to the entire service provision system, and users need not know exactly which authority or service provider they need to contact (Saarelainen et al., 2018). As low-threshold guidance centres, they enable young people to access services without an appointment, so improving outreach to individuals with unfulfilled service needs (Törmä, 2009). However, improved access to low-threshold services is not a given but rather depends on the service content, goals and users. For some, the threshold may still prove too high. Staff members and stakeholders have emphasised that if centres concentrate excessively on young people with multiple problems, this may lead to a situation where others who could benefit from the services choose not to access 
them for fear of being stigmatised. On the other hand, they highlight that if the focus is excessively on employment and career guidance, this may raise the bar for those whose primary needs relate more to social and health issues (Nieminen, 2018). All services offered by One-Stop Guidance Centres are non-compulsory, and young people can even visit the centres anonymously. In fact, many of the customers are walk-ins looking for advice.

The essential purpose of these centres is to provide information, advice and guidance to young people in relation to any relevant service available for them, including PES employment services, Social Insurance Institution of Finland benefits, health and mental health services, services for substance abusers, municipal social services, study counselling, job coaching, youth work outreach and youth workshops. As well as group sessions, young people can access individual counselling and guidance regarding employment or education, life management and career planning and the development of social and other skills required in everyday life. Social workers and nurses can provide counselling in health and social security issues, and there are recruitment events. The centres collaborate with companies to promote youth employment opportunities in their region. Beyond face-to-face services, a nationwide online guidance service for young people is in development and will be commissioned at a later date. Young people have emphasised the importance of both face-to-face and digital services, which can complement each other if properly implemented (Kettunen \& Sampson, 2019; Kettunen, Sampson, \& Vuorinen, 2015; Saarelainen et al., 2017).

The professionals who staff the centres remain employees of their host organisation (e.g. the municipality, educational institution, the social insurance institution or public employment service) but are based on the premises. The work in centres is based on agreed practices and the conscious development of a transdisciplinary approach in the guidance processes. Transdisciplinary collaboration entails a shift from traditional expert services and established networks to a dynamic combination of independent and communal ways of working. The professionals' inputs vary from full-time to collaborative periodic sessions (Sorsa, 2019). This collaboration-based service model (Sampson et al., 2017; Sveriges Kommuner och Landsting, 2017) is flexible and agile, and new services can be added as and when demand arises (Saarelainen et al., 2018).

The centres are governed by national guidelines (Figure 20.1) and crossministerial strategic planning. Operations align with national goals, and activities are shaped by those goals. Key performance indicators are developed continuously to assess concrete outcomes and impacts.

\section{Emerging Outcomes}

According to professionals involved in designing and delivering the service, the Finnish One-Stop Guidance Centre model is unlikely to have been as ambitious 


\section{Goals guiding the operations of One-Stop Guidance Centers}

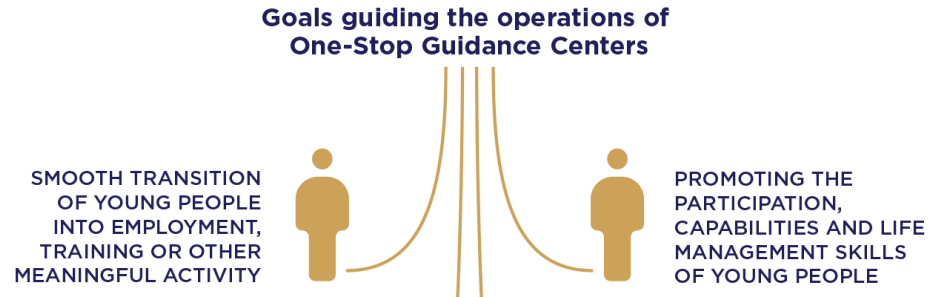

Indicators of the model's success:

1. Shorter periods of unemployment among young people.

2. Reduced number of young people on long-term social assistance.
BRINGING TOGETHER SERVICE PROVIDERS TO FORM ONE MULTIAGENCY OPERATOR

Indicators of the model's success:

1. The One-Stop Guidance Centers offer many different types of support.

2. The One-Stop Guidance Centers form a dynamic network interlinked with other welfare services.

3. The One-Stop Guidance Centers operate as a national development network for multi-agency services.
Indicators of the model's success:

As customers of the One-Stop Guidance Center,

1. Young people participate in assessing their own situation and implementing the change.

2. Young people gain readiness to plan their own futures.

3. Young people have a chance to engage in a goal-oriented activity.

THE GOALS STEERING THE OPERATIONS ARE UNDER SYSTEMATIC MONITORING

Indicators of the model's success:

There is up-to-date and accessible data on the attainment of different goals
1. Nationally.
2. Regionally.
3. Locally.

Figure 20.1. Goals guiding the operations of One-Stop Guidance Centers (from MEAE, 2018, p. 2)

in terms of scale or multi-professionalism without European funding (Ahmed, Reynolds, Stanley, Gulyurlu, \& Gabriela, 2017). One major challenge was to transform this into a permanent practice and to convince key stakeholders to remain on board, especially once ESF funding had ended (Savolainen, 2018). With increasing evidence of the model's impact, it has become easier to achieve this.

The multi-professional approach has enabled participating professionals to learn more about previously unconnected services and fields and the roles of different agencies and partners (e.g. Ahmed et al., 2017; Saarelainen et al., 2017). Barriers between the various public and private sector actors have been removed, and cooperation has improved. In the communities of practice literature, there is frequent 
reference to boundary spanning, describing the challenges faced by two or more organisations in understanding each other and achieving a level of collaboration that supports information sharing and, more importantly, production of new knowledge through joint learning and problem solving (e.g. Harvey, Peterson, \& Anand, 2014; Valkokari et al., 2014). When professionals work well together, costs can be lowered, services are not duplicated, and the identification and response to persons needs can occur more quickly (Richardson \& Patana, 2012). Co-location of all service providers also contributes to improved service delivery.

Although there has been a general reduction in youth unemployment in Finland in locations served by a one-stop guidance centre, this cannot be attributed to the centres alone (Adams, 2018). The One-Stop Guidance Centres offer different types of services and accurately tracking customers is challenging. The Centres can guide young people to contact a project outside a Centre but it is difficult to measure what the impact of the One-Stop-Shop Guidance Centre is in such a case. It may lead to a positive result for the young person but how much of it can be attributed to the Guidance Centre itself is difficult to establish. The Finnish PES is therefore working on developing a tracking system to create more accurate follow-up data (Savolainen, 2017).

There has been an attempt to collect data on the transitions made by the young people visiting the One-Stop Guidance Centers (Määttä, 2018). These records are based on fragmented registers specific to an individual administrative branch or to a locality and concern only part of the One-Stop Guidance Centre visitors. The indicative transition records suggest that of those visitors who find a solution to their need the most likely outcome is to be employed, apply for and receive a place leading to a degree, secure a rehabilitation job, work trial or job coaching, or to find an apartment (Määttä, 2018). Recent data from the centres' nationwide feedback on guidance indicated an average client satisfaction rate of 9.25 (ranging from a lowest score of 4 to a highest score of 10) (Määttä, 2018). The open-ended questions found that participants' experiences were $97 \%$ positive, and they felt they were able to contribute to decisions about their own lives. Interviews with a small number of One-Stop Guidance Centre visitors revealed that young people who had experienced both the integrated service model of the One-Stop Guidance Centre and the previous public service employment model found the former of greater value in finding a job or training opportunity and sourcing information (Sorsa, 2016).

\section{CONCLUSION}

The One-Stop Guidance Centres for young people have become one of the Finnish Government's spearhead projects. The network continues to evolve and develop, and the centres have been showcased as an example of what can be achieved with ESF funding. Adopted as a permanent measure during the government period 20152019, the centres now extend throughout Finland and offer a wider range of services 
than initially planned. The operating model is based on local contracts and depends on strong partnerships between multiple actors, as well as new operating practices and skills in multi-sector management. Co-locating different public services under one roof, involving users and stakeholders in designing services and creating new forms of 'public-private-people partnership', the One-Stop Guidance Centre model reflects the ideas of New Public Governance (Osborn, 2006, 2010), with a strong focus on collaboration and horizontal ties between individuals and agencies. The centres are a good example of horizontal policy integration, in which a single point of access facilitates information and referral to the right service, showing how more effective collaboration can lead ultimately to fuller use of higher-quality resources and services. In a further development, digital solutions and services will play a significant role in reaching and serving young people in more remote areas. The next long-term goal is to establish similar centres or an equivalent service model for all age groups.

\section{REFERENCES}

Adams, E. (2018). Addressing youth unemployment through outreach, activation and service integration. Technical dossier number 9. Luxembourg: Publications Office of the European Union. doi: $10.2767 / 441295$

Ahmed, N., Reynolds, S., Stanley, I., Gulyurtlu, S., \& Gabriel, M. (2017). How is EU employment policy driving social innovation? Deliverable 2.2 of the project Impact of the Third Sector as Social Innovation (ITSSOIN). Brussels, Belgium: European Commission

Arnkil, R., Spangar, T., \& Vuorinen, R. (2017). Pratitioner's toolkit for PES building career guidance and lifelong learning. Luxembourg: Publications Office of the European Union.

Bors Borbély-Pecze, T., \& Hutchinson, J. (2013). The youth guarantee and lifelong guidance. ELGPN Concept Note No. 4. Jyväskylä, Finland.

Bussi, M., \& Geyer, L. (2013). Youth Guarantees and recent developments on measures against youth unemployment. A mapping exercise, Background analysis 2013.04, European Trade Union InstituteETUI.

ELGPN [European Lifelong Guidance Policy Network]. (2010). Lifelong guidance policies: Work in progress. A report on the work of the European Lifelong Guidance Policy Network 2008-2010. Jyväskylä, Finland: University of Jyväskylä.

Escudero, V., \& López Mourelo, E. (2015). The youth guarantee programme in Europe: Features, implementation and challenges (International labour office Research Department Working Paper No. 4). International Labor Office.

Escudero, V., \& López Mourelo, E. (2017). The European youth guarantee: A systematic review of its implementation across countries (Research Department Working Paper No. 21). International Labor Office.

Escudero, V., Kûhn, S., López Mourelo, E., \& Tobin, S. (2018). Youth labour market prospects and recent policy developments. In M. A. Malo \& A. Moreno Mínguez (Eds.), European youth labour markets: Problems and policies (pp. 7-26). Cham: Springer. doi:10.1007/978-3-319-68222-8_2

European Commission. (2012). Proposal for a council recommendation on establishing a youth guarantee. No. 729, final, December. Brussels, Belgium: European Commission.

European Commission. (2013). Working together for Europe's young people. A call to action on youth unemployment. Brussels, Belgium: European Commission.

European Council. (2013). Council recommendation of 22 April 2013 on establishing a youth guarantee. No. 2013/C 120/1, April. Brussels, Belgium: European Council. 


\section{J. KETTUNEN \& T. FELT}

Eurostat. (2019). Unemployment statistics. Luxembourg: Eurostat. Retrieved from https://ec.europa.eu/ eurostat/statistics-explained/index.php/Unemployment_statistics\#Youth_unemployment

Eurostat. (n.d.). Statistics explained. Youth unemployment. Luxembourg: Eurostat. Retrieved from https://ec.europa.eu/eurostat/statistics-explained/index.php/Youth_unemployment\#Definition_of_ unemployment_and_youth_unemployment_indicators

Grunfelder, J., Rispling, L., \& Norledn, G. (Eds.). (2018). State of the Nordic region 2018. Theme 2: Labour force. Copenhagen, Denmark: Nordic Council of Ministers. doi:10.6027/NORD2018-001

Halvorsen, R., \& Hvinden, B. (2015). New policies to promote youth inclusion: Accommodation of diversity in the Nordic welfare states. Copenhagen, Denmark: Nordic Council of Ministers.

Harvey, S, Peterson, R. S., \& Anand, N. (2014). The process of team boundary spanning in multiorganizational contexts. Small Group Research, 45, 506-538. doi:10.1177/1046496414534474

Harju, H., Kettunen, A., Korkeamäki, J., Piirainen, K., Pitkänen, S., Pulliainen, M., Saares, A., Shemeikka, R., \& Tuusa, M. (2014). Yhdessä tekeminen tuottaa tuloksia: nuorisotakuun tutkimuksellisen tuen loppuraportti: Toimeenpanon ensimmäisen vuoden arviointi ja seurannassa sovellettavien indikaattoreiden kehittäminen [Co-operation for results. Final report on the research support for the youth guarantee programme. Evaluation of the first implementation year 2013 and development of the monitoring and evaluation indicators]. Ministry of Employment and the Economy Publications, Employment and entrepreneurship 15/2014. Helsinki, Finland: Edita Publishing.

Hellerman, M. K. (1975). One-stop shopping for social services. Social Work, 20, 91-92.

Hooley, T. (2014). The evidence base on lifelong guidance. A guide to key findings for effective policy and practice (ELGPN Tools No. 3). Jyväskylä.

Hummeluhr, N. (1997). Youth guarantees in the Nordic countries. Paper commissioned by the OECD Secretariat to provide background for the Transition Thematic Review.

ILO [International Labour Oranization]. (2013). Youth guarantees: A response to the youth employment crisis? Employment policy brief. Geneva: Employment Policy Department.

Kautto, T., Korpilauri, T., Pudas, M., \& Savonmäki, P. (2018). The beginning and early challenges. In M. Määttä (Ed.), One-stop guidance center - Ready to offer multi-agency services for the young (pp. 8-11). Jyväskylä, Finland: Kohtaamo (ESF), ELY-Center Central Finland.

Keränen, H. (2012). Young people within services - Best practices for the promotion of the youth guarantee. Ministry of Employment and the Economy. Employment and entrepreneurship department.

Kettunen, J., \& Sampson Jr., J. P. (2019). Challenges in implementing ICT in career services: Perspectives from career development experts. International Journal for Educational and Vocational Guidance, 19, 1-18. doi:10.1007/s10775-018-9365-6

Kettunen, J., Sampson Jr., J. P., \& Vuorinen, R. (2015). Career practitioners' conceptions of competency for social media in career services. British Journal of Guidance \& Counselling, 43, 43-56. doi:10.1080/ 03069885.2014.939945

Mascherini, M. (2012). Youth guarantee: Experience from Finland and Sweden. Dublin: European Foundation for the Improvement of Living and Working Conditions.

Minas, R. (2014). One-stop shops: Increasing employability and overcoming welfare state fragmentation? International Journal of Social Welfare, 23, 40-53. doi:10.1111/ijsw.12090

Ministery of Economic Affairs and Employment of Finland (MEAE). (2018). The one-stop guidance center model. Helsinki, Finland: MEAE. Retrieved from https://tem.fi/documents/1410877/2937056/ The + One-Stop + Gudance + Center + model

Mohr, J., \& Spekman, R. (1994). Characteristics of partnership success: partnership attributes, communication behaviour, and conflict resolution techniques. Strategic Management Journal, 15, 135-152. doi:10.1002/smj.4250150205

Määttä, M. (2018). General information about one-stop guidance center - The use of the services and user feedback. In M. Määttä (Ed.), One-stop guidance center - Ready to offer multi-agency services for the young (pp. 12-18). Jyväskylä, Finland: Kohtaamo (ESF), ELY-Center Central Finland.

Ng, S. T., Wong, J. M. W., \& Wong, K. K. W. (2013). A public private people partnerships (P4) process framework for infrastructure development in Hong Kong. Cities, 31, 370-381. doi:10.1016/ j.cities.2012.12.002 
Nieminen, J. (2018). The one-stop guidance centers and the social engagement of young people. In M. Määttä (Ed.), One-stop guidance center - Ready to offer multi-agency services for the young (pp. 33-35). Jyväskylä, Finland: Kohtaamo (ESF), ELY-Center Central Finland.

Notkola, V., Pitkänen, S., Tuusa, M., Ala-Kauhaluoma, M., Harkko, J., Korkeamäki, J., ... Puumalainen, J. (2013). Nuorten syrjäytyminen. Tietoa, toimintaa ja tuloksia? [Youth exclusion. Information, actions and results?]. Eduskunnan tarkastusvaliokunnan julkaisu 1/2013. Helsinki, Finland: Eduskunta. Retrieved from https://www.eduskunta.fi/FI/tietoaeduskunnasta/julkaisut/Documents/trvj_1+2013.pdf

Official Statistics of Finland. (2016). Työvoimatutkimus [Labour force survey]. Helsinki: Statistics Finland.Retrieved fromhttps://tilastokoulu.stat.fi/verkkokoulu v2.xql?course id=tkoulu tmt\&lesson $\mathrm{id}=5 \&$ subject_id $=8 \&$ page_type $=$ sisalto

O'Higgins, N. (2010). The impact of the economic and financial crisis on youth employment: Measures for labour market recovery in the European Union, Canada and the United States, Employment Sector (Employment Working Paper No. 70). Geneva, Switzerland: International Labour Organization.

Olofsso, J., \& Wadensjö, E. (2012). Youth, education and labour market in the Nordic countries similar but not the same. Berlin, Germany: Friedrich Ebert Foundation.

O’Reilly, J., Eichorst, W., Gábos, A., Hadjivassiliou, K., Lain, D., Leschke, J., ... Villa, P. (2015). Five characteristics of youth unemployment in Europe: Flexibility, education, migration, family legacies, and EU policy. Sage Open, 5(1), 1-19. doi:10.1177/2158244015574962

Organisation for Economic Co-operation and Development (OECD). (2004). Career guidance and public policy: Bridging the gap. Paris: OECD.

Organisation for Economic Co-operation and Development (OECD). (2015). Local implementation of youth guarantee: emerging lessons from Europan experiences. Paris: OECD.

Organisation for Economic Co-operation and Development (OECD). (2019a). Getting skills right: Future-ready adult learning systems. Paris: OECD Publishing. doi:10.1787.9789264311756-en

Organisation for Economic Co-operation and Development (OECD). (2019b). Investing in youth: Finland. Paris: OECD Publishing. doi:10.1787/1251a123-en

Osborne, S. P. (2006). The new public governance? Public Management Review, 8(3), 377-387. doi:10.1080/14719030600853022

Osborne, S. P. (Ed.). (2010). The new public governance: Emerging perspectives on the theory and practice of public governance. London: Routledge.

Prime Minister's Office Finland. (2018). Finland, a land of solutions: Government action plan 2018-2019. Finnish government publication series 29/201. Retrieved from http://julkaisut.valtioneuvosto.fi/ bitstream/handle/10024/160985/29_18_Finland_a_land_of_Solutions_2018-2019_EN.pdf

Richardson, D., \& Patana, P. (2012). Integrating service delivery: Why, for who, and how? (OECD discussion paper). Paris: OECD.

Saarelainen, T., Mäensivu, S., \& Minkkinen, J. (2018). The one-stop guidance center as an ecosystem. In M. Määttä (Ed.), One-stop guidance center - Ready to offer multi-agency services for the young (pp. 23-29). Jyväskylä, Finland: Kohtaamo (ESF), ELY-Center Central Finland.

Sampson Jr., J. P., \& Reardon, R. C. (1998). Maximizing staff resources in meeting the needs of job seekers in one-stop centers. Journal of Employment Counseling, 35, 50-68. doi:10.1002/ j.2161-1920.1998.tb00476.x

Sampson Jr., J. P., McClain, M.-C., Musch, E., \& Reardon, R. C. (2017). The supply and demand for career and workforce development programs and services as a social justice issue. In V. S. Solberg \& S. R. Ali (Eds.), The handbook of career and workforce development: Research, practice, and policy (pp. 57-75). New York, NY: Routledge.

Savolainen, J. (2017). One-stop-shop guidance centres for young people (Ohjaamo). Retrieved from https:/ec.europa.eu/social/main.jsp?catId=1206\&langId=en

Savolainen, J., Virnes, E., Hilpinen, M., \& Palola, E. (2015). Nuorisotakuu-työryhmän loppuraportti ja suositukset jatkotoimiksi [Final report of the youth guarantee working group]. Työ- ja elinkeinoministeriön julkaisuja. Työ ja yrittäjyys 19/2015.

Sorsa, K. (2016). Case study briefing: Youth guarantee and one-stop guidance center. Finland. Innovative Social Investment Strengthening communities in Europe, Innosi-project report. Retrieved from http://innosi.eu/wp-content/uploads/2017/04/FINLAND-Youth-Guarantee.pdf 
Sorsa, K. (2019). The youth guarantee and one-stop-guidance centers as a social innovation and a policy implementation tool in Finland. In S. Baines, A. Bassi, J. Csoba, \& F. Sibos (Eds.), Implementing innovative social investment: Strategic lessons from Europe (pp. 83-96). Bristol: Policy Press.

Sveriges Kommuner och Landsting. (2017). One-stop guidance center: Successful method. Successful method for youth transition to labour market. Stockholm: Sveriges Kommuner och Landsting.

Törmä, S. (2009). Kynnyskysymyksiä: Huono-osaisimmat huumeiden käyttäjä ja matala kynnys [Threshold questions: The most marginalized drug users and low threshold]. Helsinki, Finland: Sosiaalikehitys Oy.

Valkokari, K., Salminen, J., Rajala, A., Koskela, M., Kaunisto, K., \& Apilo, T. (Eds.). (2014). Ekosysteemit ja verkostojen parviäly [Ecosystems and swarm intelligence of networks: Agenda for future networked business]. Espoo, Finland: VTT Technology 152. 